\title{
Redimindo Masculinidades: Representações e significados de masculinidades e violência na perspectiva de uma teologia pastoral Amazônica
}

\author{
Orientador: Abimar Oliveira de Moraes \\ Doutorando: Ricardo Gonçalves Castro \\ Área de Concentração: Teologia Sistemático-Pastoral \\ Linha de Pesquisa: Fé e Cultura \\ Projeto de Pesquisa: Questões atuais de Teologia Pastoral
}

A tese analisa a relação entre as masculinidades, violência e religiosidade a partir do contexto Amazônico. Esta se volta para os significados das masculinidades encarnadas nas representações elaboradas dentro dos contextos interculturais e históricos da religiosidade amazônica. Masculinidades no plural quer expressar a diversidade de expressões que se constrói tanto na vida das pessoas, como nas expressões culturais e religiosas. A pesquisa usa da metodologia das teologias contextuais da libertação, porque se elabora a partir de aspectos da realidade cultural-religiosa de onde deriva compreensões críticas das representações teológicas sobre as masculinidades. As mediações teóricas são elaboradas a partir das perspectivas teológicas de gênero, feminista, pós-colonial e intercultural. O problema central desta pesquisa é a relação entre os vários significados de masculinidades presente nas representações religiosas e teológicas, como causa de violência ou possibilidade de redenção. A hegemonia de uma masculinidade construída a partir de estruturas coloniais violentas, princípios racionais e teológicos patriarcais, ao ser desconstruída, abre a possibilidade de melhor compreender e enriquecer a vivência humana nos seus modos plurais, no contexto Amazônico. Esta reflexão teológica procura oferecer significados teológicos atualizados, para que a vida humana e suas relações, sejam transformadas e manifestem os sinais do Reino de Deus. Masculinidades, são colocadas na esfera da história, da cultura e da religião que os homens habitam, elas são interculturais, hibridas, ou seja, não são es- 
táveis, mas estão em constante processo de reformulação. Essa constatação é um aspecto importante para pensar possibilidades pastorais do cuidado de homens no âmbito eclesial. Uma antropologia pastoral das masculinidades se fundamenta na perspectiva trinitária e kenótica, na releitura de suas representações bíblico-teológicas: êxodo, páscoa, kénosis, morte e ressurreição - da escravidão para a liberdade de filhos e filhas, da morte para a vida em plenitude. Masculinidades redimidas na Amazônia bebe das fontes cristãs, mas também da cultura milenar de seus povos, tornando-se ecológicas. A formação e vivência de novas identidades masculinas necessitam de processos iniciáticos, ou seja, adquirir uma consciência de si mesmo como pessoa - adquirir compreensão da corporeidade espiritual, subjetiva, intersubjetiva e chamada a vivência comunitária.

Palavras-chave: Masculinidades. Redenção. Cultura-religiosa amazônica. 